\title{
Institutions of Coordination in Mixed Market Economies: The Gatekeeper Role of the State in Labour Relations
}

\author{
Francesco Galletti \\ Salzburg Centre of European Union Studies, University of Salzburg, Austria
}

Copyright(C2018 by authors, all rights reserved. Authors agree that this article remains permanently open access under the terms of the Creative Commons Attribution License 4.0 International License

\begin{abstract}
According to the Varieties of Capitalism (VoC) approach, the gatekeeper role of the state is a key feature in the Mixed Market Economies (MMEs) coordination channel. Relying upon the ICTWSS dataset, the article investigates how this role was concretely deployed in the labour relations dimension. Special consideration is given to ground how this role took place before the path towards the EMU was set as well as to sketch out the dynamics of change that followed afterwards A close inspection of the coordination channel allows, indeed, completing the picture about the juxtaposition between Mixed and Coordinated Market Economies that the distributive costs stemming from the Euro-crisis has made extremely salient.
\end{abstract}

Keywords VoC, Mixed Market Economies, Labour Relations, Coordination Channel

\section{Introduction}

The cross-country redistributive costs brought about by the Euro-crisis constituted an extremely interesting case to be addressed within a comparative capitalism tradition [1]. A variety of Capitalism ( $\mathrm{VoC})$, which to a great extent is the prevailing approach in the field, was no exception in this regard. Yet, the $\mathrm{VoC}$-based literature focusing on institutional heterogeneity of the EMU [2,3,4,5,6,7], agreed in individuating the Mixed Market Economies as the variety mostly affected by the EMU's institutional framework. This claim has remarkable implications, given that the overall VoC approach was originally built upon the dichotomous distinction between Liberal and Coordinated Market Economies (LMEs and CMEs respectively), leaving mid-spectrum cases in a sort of underspecified conceptual limbo. However, even restricting the focus to Western Europe, the dichotomy LMEs/CMEs falls short in covering the full array of institutional variation. Also, given the relevance of the countries not fitting the dichotomy, i.e. Italy, Spain, Portugal, Greece and even France, a third variety, denominated Mixed Market Economies, was eventually introduced.

Rhodes and Molina (8) were the first to define this variety in a consistent $\mathrm{VoC}$ framework by introducing the notion of gatekeeping, to account for the peculiar role held by the state in these political economies. This role retained by the state is a fundamental part of the coordination channel occurring in the Mixed Market Economies, indeed. In this respect it is important to emphasize that coordination mechanisms and institutional complementarities that any socio-economic model - i.e. variety - develops and supports, are the key determinants to understanding the institutional resilience scheme proposed in $\mathrm{VoC}$ literature. In other words, a clearly defined channel of coordination and the institutional complementarities originating from it are key determinants in the cross-variety differentiation. The conceptual pitfall concerning MMEs lies exactly here, as both complementarities and coordination channel of this variety were not systematically addressed but remained substantially concealed behind the peculiar role of the state. This shortage became even more striking, once the balance of payment disequilibria $[9,10]$ that ultimately led to the Euro-crisis, revealed their full implications for $\mathrm{VoC}$-based comparative analyses, namely the main juxtaposition in the EMU to be the one between CMEs and MMEs. It is obvious that a fruitful comparison and the assessment of the divergent trends among varieties, before and after the crisis, can be conceived only if the two varieties lay at the same level; meaning that both CMEs and MMEs should have institutional complementarities and clearly defined coordination mechanisms.

The overall aim of this research is, therefore, filling this gap concerning complementarities and channels of coordination in the MMEs, by scrutinizing how the 
gatekeeper role of the state is deployed in labour relations. Reaching coordination in the wage bargaining process is a fundamental aspect of any variety and the availability of the ICTWSS dataset [11] makes it possible to investigate the gatekeeper role held by the state - i.e. the fundamental feature in the MMEs' channel of coordination - in a crucial dimension of the domestic political economies, like the labour one. Special consideration is given to how the gatekeeping role was deployed before the path towards the European Monetary Union was set, as well as to sketch out the dynamics of change that the EMU itself introduced. The Maastricht Treaty, indeed, by signalling a new regulatory phase to which the states have to comply, constituted a crucial step for the domestic political economies involved in the process and a powerful external pressure to which the MMEs needed to adjust. Due to the aforementioned claims about the MMEs being the variety most affected by the EMU institutional configuration, making this distinction between pre-Maastricht and post-Maastricht phases acquires even more relevance.

The remainder of the article is structured as follows. Section 2 stresses the importance of institution complementarities and coordination channels in the $\mathrm{VoC}$ perspective and illustrates why the gatekeeper role of the state is the key factor in the MMEs. Section 3 is devoted to showing the chosen data and methods before the subsequent two sections turn to the analytical work. Specifically, section 4 is aimed at grounding the cross-variety differences in state intervention during the $70 \mathrm{~s}$ and the $80 \mathrm{~s}$, as well as to identify the changes that occurred when the Maastricht Treaty was signed and the path towards the EMU was set. Section 5 adopts a within-variety perspective on the MMEs and tackles the reconfiguration of state intervention in the post-Maastricht phase by emphasizing the role of social pacts and state sponsored agreements. Finally, section 6 summarizes the new elements introduced in the research and gives brief conclusions.

\section{Gatekeeper Role of the State in MMEs: Rationale and Underlying Basis}

Channels of coordination and institutional complementarities owned by any socio-economic model are key determinants in understanding institutional resilience in a Varieties of Capitalism $(\mathrm{VoC})$ perspective. This approach acquired a prominent position in Comparative Political Economy (CPE), thanks to its firms' based model of institutional resilience, showing that globalization does not necessarily lead to convergence. The persistence of at least two varieties on which $\mathrm{VoC}$ was originally built effectively challenged the convergence hypothesis emphasized, amongst others, by Cerny $[12,13]$ or Rajan and Zingales [14]. Yet, VoC proponents [15,16] contend that a specific channel of coordination emerging in one sphere of the economy is likely to enhance similar practices in the contiguous spheres, leading to different institutional complementarities in any domestic setting. Following Hall and Gingerich [17], institutions are functioning in a complementary way if all the constitutive features of a peculiar political economy configuration strengthen each other and engender a strong and continuative effect. In a nutshell, the institutional complementarities are based upon differences in the coordination channel and the link between those two aspects is the cornerstone to account for institutional resilience within a $\mathrm{VoC}$ formulation.

As anticipated in the introductory section, this rationale can be - explicitly or implicitly - individuated in the accounts distinguishing between Coordinated and Liberal Economies but remains underexplored, once the attention is shifted towards the Mixed Economies where the state was simply assumed to play a different role without clearly defining the differences. It doubts about the sustainability of this model in a globalised economy and the persisting difficulty in defining the conceptual boundary of state intervention (e.g. active role in promoting innovation and competitiveness or simply defensive tool in the face of the external changes) opened-up a huge debate as to why this third variety exists. For instance, Della Sala [18] raising the notion of MMEs as a dysfunctional variation of the continental model seems to neglect this possibility. In a similar vein, Simoni [19] linked the Italian economic decline to a progressive hybridisation of the domestic model of capitalism that, in the initial period after-WWII, was very close to the strategic interaction model proper of CMEs.

In other, terms, the flaws in defining the conceptual boundaries of state intervention in MMEs led to the paradoxical conclusion of considering this variety as a dysfunctional variation of the Coordinates continental one. Even taking aside the empirical difficulties stemming from the definition of an entire group of countries as dysfunctional, an evident shortage would emerge in the comparative analysis of the EMU where the main distinction is commonly individuated to be between Coordinated and Mixed economies. A useful comparison of the existing imbalances between the two sides requires that the two varieties lay at the same level. A comparative account in which a dysfunctional variety is more affected than a fully-fledged one by EMU-specific policies and constraints, indeed, would seriously incur the risk of cyclical or self-explanatory argument.

The importance of institutional complementarities and coordination mechanisms to have a Mixed Economies variety in place, led Rhodes \& Molina [20] to introduce the peculiar gatekeeping function of the state in the coordination channel. This was, indeed, the first attempt to empirically ground the difference of the MMEs coordination channel from the ones that characterize the 
Liberal and the coordinated counterparts. Moreover, whereas both LMEs and CMEs have bottom-up coordination mechanisms - via market or strategic interaction respectively - the MMEs own a top-down state-mediated one. Hancké [21] gave an effective micro-foundation of this mechanism by emphasizing a two-tiered framework where firms try to coordinate amongst themselves but are ultimately obliged to rely upon the state to compensate for the gaps preventing them delivering autonomously. Despite the relevance of the gatekeeper role of the state for the MMEs coordination channel, a shortage in the literature still exists, concerning how this role is deployed across the different spheres of the domestic political economies. This article then attempts to analyze bases and modifications of the gatekeeper role in the sphere of labour relations. A prominent reason underlying it is the fragmentation among socio-economic agents characterising the MMEs. In other terms, the gatekeeping state is necessary to overcome the idea that only LMEs and CMEs could develop the complementarities among domestic sub-systems that are ultimately necessary for a stable institutional equilibrium being in place.

Yet, this specific coordination mechanism originates from the high fragmentation characterizing the MME political economies. For instance, fragmentation exists among employers and employee organizations, both in longitudinal terms (small vs. large enterprises) and in sectoral ones (public vs. private sectors), so that bottom-up coordination occurring among the CMEs wage bargainers is very difficult to replicate in the MMEs. Then, another relevant aspect to be considered concerns the production lines. In the MMEs - sharing a demand-led model of growth $[22,23,24]$ - the residual role of low value-added production is higher than elsewhere. In turn, his fact leads to an underspecified innovation pattern, as opposed to both CMEs and LMEs that are commonly identified to be supportive of incremental and radical innovation respectively [25]. Furthermore, low value-added productions are also the most exposed to international competition. In this regard, De Ville and Vermeiren [26] empirically showed that the rise of China in the world economy constituted an external shock for the MMEs, because those countries were less institutionally ready -i.e. their productions were mainly low value-added ones - to face this challenge.

Given fragmented interests and the impossibility of reaching coordination via bottom-up mechanisms, the gatekeeper role held by the state is a necessary feature in having a functioning and stable system. In order to emphasize the institutional complementarities that this feature should engender, let me consider the interrelations between three fundamental sub-systems of any political economy: the welfare state, production regimes and the political system. Arguing that the gatekeeper role is the crucial element in the coordination channel proper of the MMEs requires tackling the linkages among these dimensions and figuring out the complementarities that can be originated from them. As a matter of fact, political economies not fitting the two archetypes, such as the MMEs, may be less effective in some areas and produce looser complementarities but they may still confer enough benefits on key players to support their institutional stability $[27,28]$. Figure 1 is therefore conceived to visually display the linkages among the aforementioned sub-systems through a flow chart representing the MMEs' domestic political economies.

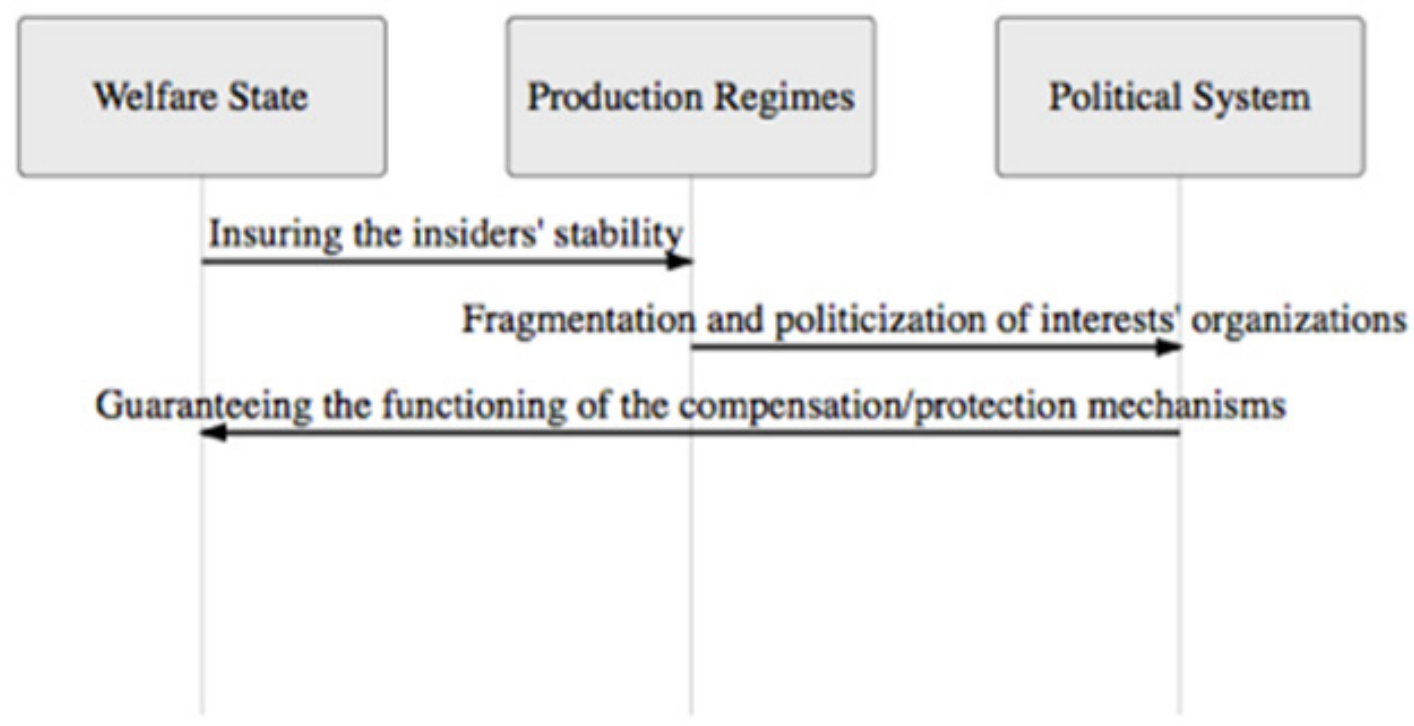

Figure 1. Linkages among domestic sub-systems in the MMEs 
Starting with the welfare state provisions, it is possible to trace back the definition of a proper Southern European model of welfare in Ferrera [29] and Ferrera and Gualmini [30]. This model results from a combination of universal health services and minimal social security, mostly based on pensions, and it is generally aimed to complement the persisting role of the family. In other terms, the welfare system in not conceived, as in the CMEs, to guarantee the specific skills that workers are required to acquire, but rather to insure the insiders' stability. A prioritization of the insiders at the expense of the outsiders is particularly relevant in these contexts, where training is mostly oriented to the general skills and low value-added manufacturing representing a significant part of the production regimes. Yet, this prioritization typically entails social policies leaning towards the consumption side, rather than to the investment one [31]. Moreover, fragmented production regimes, - i.e. the presence of many divides like public vs. private or big vs. small businesses -, usually lead to highly fragmented and politicized interests' organizations too. Fragmentation of the interests' organizations ultimately impedes the bottom-up coordination to occur but do not prevent the same organizations from constituting powerful veto players that the political system needs to consider. Thus, in political economies where fragmentation is predominant and the strongest societal groups are small businesses and organized insiders, demands for compensation and protection in labour relations or in the sphere of welfare systems are expected to be higher than elsewhere. Also, the political system ultimately guarantees the proper functioning of these compensation/protection mechanisms.

The nature of the state emerging from those linkages is clearly a compensatory one, implying regulatory activities conceived to safeguard insiders and potential losers of globalization, as well as to correct coordination failures. A compensatory state, proper of the MMEs, is therefore different from both the minimum state of the LMEs guaranteeing the effective functioning of the market mechanisms and from the CMEs' one, where the institutions enabling strategic coordination are safeguarded. Thus, the gatekeeper role of the state emerges as the key determinant in the MMEs' coordination channel and, ultimately, as the necessary feature allowing them to compete in the international scenario. Indeed, without the state acting as a facilitator among differentiated and fragmented interests, no institutional complementarities and no coordination would be possible. It is therefore important to understand how this key determinant was deployed and evolved in a relevant political economy sphere like labour relations; an issue I now turn to.

\section{Methods and Data}

Labour relations are the chosen sphere to investigate the evolution of the gatekeeper role of the state. In order to test this role in different phases of the Europeanization process - and due to the fact that the main MMEs are also part of the EMU - the case selection comprises the Eurozone founding members grouped by variety. Clearly the main juxtaposition emerging in this analysis is between Coordinated (Germany, Austria, Finland, The Netherlands and Belgium) and Mixed Market Economies (Italy, France, Spain, Portugal and Greece). Liberal Market Economies in the EMU are represented in the Eurozone uniquely by Ireland.

There are a couple of valid reasons to justify the choice of labour relations. First of all, the availability of data concerning wage bargaining structures, social pacts and employment measures allows for the portrayal of how the MMEs' gatekeeping role was shaped and evolved during the years. Secondly, given the focus on Eurozone countries and the constraint to the internal adjustment the EMU membership allegedly sets, labour relations are particularly significant to target the juxtaposition between CMEs and MMEs brought about by the Euro-crisis. Yet, the relevance of labour relations in the EMU countries' adjustments to the crisis is largely recognized both in $\mathrm{VoC}$ accounts and $[32,33]$ in different political economy approaches $[34,35$, 36] In the overall set of hypotheses state intervention in labour relations is assumed to be an appropriate proxy for the gatekeeper role held by the state. In other words, state intervention in the sphere of labour relations would then be the dependent variable in the analytical research. Of course, measuring the array of state intervention is potentially a gruelling task, as the range of relevant features is extremely complex and interconnected, so that collapsing them into a single measure is a hard task. A first attempt in this direction was made by Golden, Wallerstein and Lange's dataset, covering the OECD countries in the period 1950-2000. Nowadays, the Database on Institutional Characteristics of Trade Unions, Wage Setting, State Intervention and Social Pacts (ICTWSS), elaborated upon by the Amsterdam Institute for Advanced Labour Studies (AIAS), is the most advanced tool covering a huge array of these interrelated dimensions.

The data extrapolated from the ICTWSS database are investigated relying upon simple statistical instruments. In most cases, these analytical tools are correlations, tables and boxplots, conceived to show the data distribution. The reasons underlying this choice are twofold. Firstly, and consistent with Hassel [37] one can contend that the peculiar and complex nature of the dependent variable - i.e. state intervention in the labour sphere - suggests being very conservative in terms of statistical sophistication. Secondly, the high degree of path dependency encompassed in the given variables allows to claiming that averaged data are likely to be representative of the tendency without losing their explanatory power. Moreover, the overall analytical strategy allow for figuring out few analytical elements that can be useful to grasp the 
evolution of the coordination channel in the MMEs.

Relying on the ICTWSS data, a set of hypotheses is therefore developed and tackled in this paper, to ground the gatekeeper role in the MMEs and its evolution during the years. In brief, $\mathrm{H} 1$ deals with state intervention in the wage bargaining process before the Maastricht Treaty and expects that Mixed Economies to be more interventionist than their counterparts. $\mathrm{H} 2$ completes the picture, focusing on the post-Maastricht phase and envisaging a reduction of state intervention in the same MMEs. The Maastricht Treaty, by setting the parameters to join the single currency, is therefore reputed to be a critical turning point, signalling the beginning of a new regulatory phase. Two further hypotheses integrate this point by considering social pacts as a possible reconfiguration of the role of the state in the post-Maastricht phase. Hence, $\mathrm{H} 3$ expects that, in the Mixed Economies, a reduced direct state intervention in the post-Maastricht phase will go together with an increased relevance of social pacts, involving governments, unions and employers. Eventually, $\mathrm{H} 4$ explores the relationship between social pacts and external constraint (EMU accession and fiscal rule implied by the Stability and Growth Pact). Specifically, it expects that state action through social pacts is higher when the external constraint is also higher. In other words, this last hypothesis tests the relaxation of the state's role in the wage bargaining process, once the main external constraints - i.e. securing EMU membership and the discipline envisioned by the Stability and Growth Pact - have vanished.

\section{MMEs and State Intervention in Wage Bargaining}

As previously stated, both the LMEs and the CMEs rely on bottom-up coordination mechanisms, whilst the MMEs entail the facilitating role of the state. Gauging state intervention in wage bargaining is therefore useful to draw a clear picture of the gatekeeping activity necessary to have an effective coordination channel in the MMEs. Relying upon the ICTWSS data, this measurement is firstly made concrete through two different hypotheses assuming the Maastricht Treaty to be the cornerstone signalling a new regulatory phase to which the countries subsequently adhering to the EMU - like the ones here considered - have to adapt. The related hypotheses can be synthetically formulated in the following terms:

- H1: MMEs for the period of the 1970s/1980s are expected to be more interventionist than the counterparts.

- H2: Following the Maastricht Treaty, state intervention in the MMEs is expected to decrease.

$\mathrm{H1}$ is therefore conceived to display how state intervention in the wage bargaining process was deployed during the 1970s and 1980s, whilst H2 completes the picture by referring to the post-Maastricht phase. Three variables are extrapolated from the ICTWSS database to tackle these hypotheses and to display the cross-variety differences existing in the given dimension: wage setting coordination, government intervention and the predominant level at which the bargaining takes place.

Coordination is defined as the "degree to which minor players deliberately follow along with what major players decide" [38] As it targets the degree of coordination rather than its type, wage bargaining coordination is different from centralization. This specification means that the highest degree of wage bargaining coordination, i.e. 5 in the corresponding scale, could be obtained either via centralized bargaining by peak associations or via informal centralization of industry-level bargaining. Hence, in this specific scale, a value equal to 5 indicates the highest degree of coordination, whereas 1 stands for fragmented wage bargaining, confined largely to individual firms or plants. Given this variable uniquely codes the observed degree of coordination, an effective disentanglement of the role of the state requires it to be integrated with the second one denominated as government intervention in wage bargaining [39]. Following the description offered in Visser [40], this scale assigns a score equal to 5 to the countries imposing private sector wage settlements, placing a ceiling on bargaining outcomes or suspending the bargaining itself. Going downward along the ladder, scoring 4 implies a government directly participating in wage bargaining, whereas 3 means government indirectly influences the outcomes through price-ceilings, indexation, tax measures, minimum wages and/or pattern setting through public sector wages. A score equal to 2 is assigned to the government influencing wage bargaining by providing an institutional framework of consultation and information exchange, by conditional agreement to extend private sector agreements, and/or by providing a conflict resolution mechanism which links the settlement of disputes across the economy and/or allows the intervention of state arbitrators or Parliament. Scoring 1 obviously implies that none of the aforementioned actions is conducted. Eventually, the third variable completes the picture of centralization vs. decentralization in the wage bargaining process by displaying the predominant level at which the bargain takes place and ranges from 5 (central or cross-industry level) to 1 (company level).

A comprehensive reading of these three variables allows for the grounding of the extent of state intervention taking place for the considered period of time. Specifically, table 1 displays the averaged ten years' data concerning the 1970s, whereas table 2 makes the case for the 1980s. Given the specific aim of the present research, country data are followed by variety data, aggregating the respective countries, so that the CMEs comprise Germany, Austria, Finland, the Netherlands and Belgium, whereas MMEs are Italy, France, Spain, Portugal and Greece. The LME variety is not explicated, given that among the EMU founding members only Ireland could be comprised in that 
variety; however, both the Irish and the British data are singularly displayed, in order to cover the full array of institutional variation. Indeed, including also the UK data in these two figures concerning the pre-Maastricht phase is not inconsistent with the research design, as it allows for the displaying of the score of the country that, at least from the 1980s, constitutes the European prototype of the LMEs.

A first look at the variety data displayed in Table 1 highlights how Coordinated countries register higher values in both the degree of coordination (4 against 2.7) and the bargaining level (4.1 against 3.2) than the Mixed ones. The logical and expected implication for the MMEs is for less coordination and more fragmentation in the bargaining structure, exemplified by the lower score observed in the predominant level variable, which would engender higher levels of government intervention. This expectation is matched by the data, revealing an average score equal to 3.2 for CMEs and to 3.7 for MMEs. The 0.5 difference in a five points scale seems enough to support the relevance of the alleged difference.

Table 1. Average values of the variables (1970-1979) - ICTWSS data, own elaboration

\begin{tabular}{|c|c|c|c|}
\hline Country & Coordination & $\begin{array}{c}\text { Government } \\
\text { intervention }\end{array}$ & $\begin{array}{c}\text { Predominant } \\
\text { level }\end{array}$ \\
\hline Austria & 5 & 2.4 & 5 \\
\hline Belgium & 3.7 & 2.6 & 3.6 \\
\hline Finland & 4.8 & 4.9 & 4.4 \\
\hline Germany & 3.2 & 2.7 & 3 \\
\hline Netherlands & 3.6 & 4.1 & 4.3 \\
\hline CMEs & $\mathbf{4}$ & $\mathbf{3 . 2}$ & $\mathbf{4 . 1}$ \\
\hline France & 2.2 & 3.4 & 3 \\
\hline Greece & 2.8 & 3.4 & 3.8 \\
\hline Italy & 2.6 & 2.8 & 3.3 \\
\hline Spain & 5 & 4 & 3.3 \\
\hline Portugal & 3 & 5 & 3 \\
\hline MMEs & $\mathbf{2 . 7}$ & $\mathbf{3 . 7}$ & $\mathbf{3 . 2}$ \\
\hline UK & 3.5 & 4.3 & 3.7 \\
\hline Ireland & 3.2 & 3.4 & 3.4 \\
\hline
\end{tabular}

A similar picture can be drawn from the data, referring to the 1980s, displayed in table 2. In more detail, it is extremely interesting to note that prototypical CMEs, like Germany and Austria, stabilize their scores on a high average coordination (4 and 4.3) and only 2 on the scale of government. These observations can be considered a very good approximation of the strategic interaction principle pointed out by Hall and Soskice in their path-breaking study. By contrast, among the CMEs, Belgium kept a higher coordination together with high regulative intervention. The simple fact that the CMEs' most controversial case is constituted by Belgium is hardly surprising, considering the peculiar linguistic, regional and productive divides characterizing this country. The group of countries belonging to the MME appears to be less homogeneous; France emerges as the country where wage bargaining is less coordinated and Greece the one having the highest coordination score, along with the highest level of state intervention. Moreover, comparing the 70s' with the $80 \mathrm{~s}^{\prime}$ data it is also noteworthy to notice the radical change that occurred in the UK as a result of the strong liberalization agenda enacted by the government. Eventually, looking to the variety data, a substantial stability is evident in coordination and government intervention, whereas the only relevant change seems to be a diminished distance in the predominant (sectoral) level at which the wage bargaining takes place. Consistent with the expectations inferred from their domestic fragmentation, lower coordination and higher government intervention seem to be the defining features of the MMEs in this second decade too.

Table 2. Average values of the variables (1980-1989). ICTWSS data, own elaboration

\begin{tabular}{|c|c|c|c|}
\hline Country & Coordination & $\begin{array}{l}\text { Government } \\
\text { intervention }\end{array}$ & $\begin{array}{c}\text { Predominant } \\
\text { level }\end{array}$ \\
\hline Austria & 4.3 & 2 & 3.6 \\
\hline Belgium & 4.5 & 4.6 & 4.6 \\
\hline Finland & 4 & 3.7 & 3.9 \\
\hline Germany & 4 & 2 & 3 \\
\hline Netherlands & 3.8 & 3.7 & 3.7 \\
\hline CMEs & 4.2 & 3.2 & 3.7 \\
\hline France & 2.1 & 3.2 & 3 \\
\hline Greece & 3.6 & 4 & 4.7 \\
\hline Italy & 2.4 & 3.7 & 2.6 \\
\hline Spain & 2.8 & 3.7 & 3.9 \\
\hline Portugal & 2.6 & 3.7 & 3.7 \\
\hline MMEs & 2.8 & 3.7 & 3.5 \\
\hline UK & 1 & 1 & 2.7 \\
\hline Ireland & 2.5 & 3.3 & 2.6 \\
\hline
\end{tabular}

As the specific hypothesis $\mathrm{H} 1$ deals with a higher interventionism of the MMEs countries all through the period under consideration, it is useful to complete the account by showing the boxplot of the specific variable of government intervention (Figure 2) for the overall time period. The boxplot is based on the yearly values, averaged according to the respective variety, and gives a visual account of the score distribution. The CMEs distribution for this specific variable is extremely concentrated with the 
median value equal to 3.2 that is also the most recurrent one and only two outliers on the upper side. In contrast, the MMEs' distribution is less concentrated; the median value is 3.6 and the interquartile range comprised between 3.4 and 3.8. In a nutshell, Figure 2 strengthens the claim emerging from the previous tables about a significant difference in state intervention existing across the two varieties, so that the expectation made in $\mathrm{H} 1$ seem to be matched by the data.

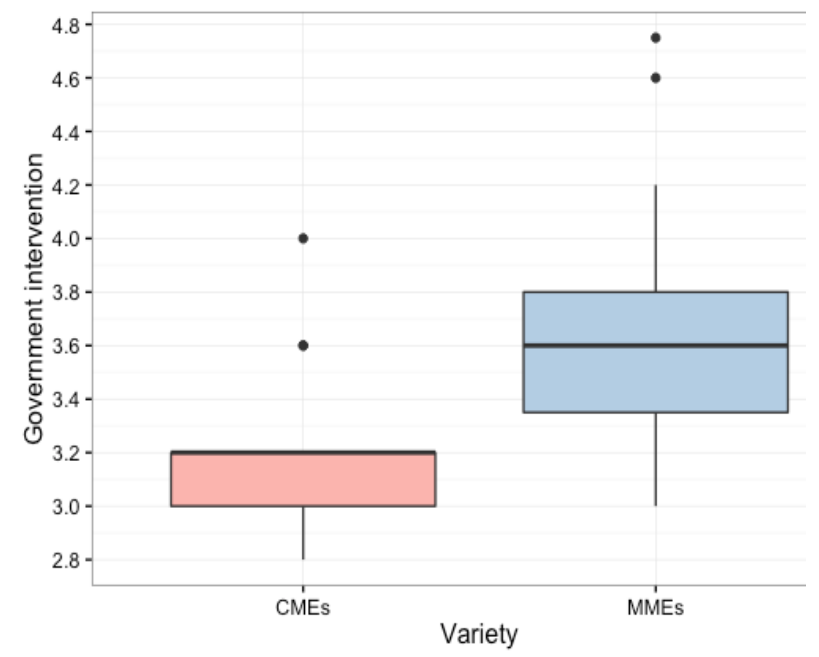

Figure 2. Linkages among domestic sub-systems in the MMEs

Once moving from $\mathrm{H} 1$ to $\mathrm{H} 2$, it is useful to restate that a different picture is expected to emerge. Increasing pressures to converge, implied by the path taken to join the EMU, should logically engender a reduced array of state intervention in the MMEs. For the sake of clarity, given the aim to portray a cross-variety comparison, in dealing with this second hypothesis only, the variety data are displayed. Thus, Figure 3 displays in a table (A-side), the averaged values aggregated according to the belonging variety and, in a boxplot (B-side) the specific variable of government intervention. Specifically, the data shown in the table are ten years' average classes for the 1990s and the 2000s, and a further five years' average class denominated Post-Crisis that merges data from 2010 to 2014. Likewise, the boxplot plotted in Figure 2, even this one, is based on the yearly values averaged according to the belonging variety.

\section{A. Government Intervention by Variety 1990-2014}

\begin{tabular}{|c|c|c|c|}
\hline Variety/Years & Coordination & $\begin{array}{c}\text { Gov. } \\
\text { intervention }\end{array}$ & $\begin{array}{c}\text { Predominant } \\
\text { level }\end{array}$ \\
\hline CMEs90 & 4 & 3.1 & 3.6 \\
\hline CMEs00 & 4.1 & 3.1 & 3.6 \\
\hline $\begin{array}{c}\text { CMEs } \\
\text { Post-Crisis }\end{array}$ & 4.3 & 3.2 & 3.6 \\
\hline MMEs90 & 2.7 & 3.2 & 3.5 \\
\hline MMEs00 & 2.9 & 2.9 & 3.3 \\
\hline $\begin{array}{c}\text { MMEs } \\
\text { Post-Crisis }\end{array}$ & 2.5 & 3.7 & 3 \\
\hline
\end{tabular}

\section{B. Boxplot: Average Intervention by Variety}

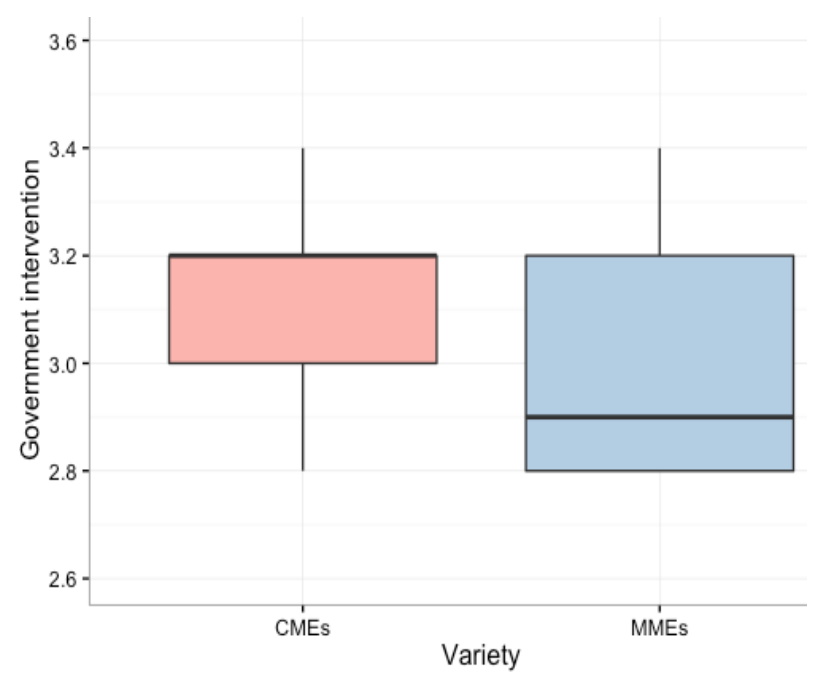

Figure 3. Cross-variety state intervention (1990-2014) - ICTWSS data, own elaboration

Looking to Figure 3 and comparing it with the previous time period, a very different picture can be drawn. Whereas both the degree of coordination and the predominant level remain substantially stable in the 1990s and the 2000s compared to the previous decades, this is not the case for government intervention. This latter variable shows a steady path for the CMEs but a downward one for the MMEs. Indeed, in the 2000s, the MMEs' score is even lower than for the CMEs. Moreover, this decreasing path goes in the expected direction and seems to confirm the relevance of the converging pressures resulting from the changes introduced after Maastricht. The post-crisis class then constitutes a very interesting case, where the MMEs show a decrease in the degree of coordination in parallel with a sharp increase in government intervention. Indeed, less coordination could imply labour market reforms oriented to favour firms' level bargaining in place of the sectorial one. In parallel, a steep increase in state intervention could signal that given the time constraints posed by the crisis emergence and the necessity to adjust, a much more proactive role of the state was required.

However, for the limited scope implied by $\mathrm{H} 2$, it is extremely relevant to emphasize the decrease in the government intervention variable observed in the 1990s and 2000s. This is exactly what the boxplot displayed in the $\mathrm{B}$-side of figure 3 has been conceived to portray. The score distribution of CMEs appears very concentrated, whereas this is not the case for the MMEs. The median value for the MMEs turns out to be even lower than the CMEs and the interquartile range covers all the CMEs' distribution. In other words, comparing the boxplots showed in Figure 2 and $3 \mathrm{~B}$, the reduction of the state's direct role in wage bargaining experienced by the MMEs in the post-Maastricht phase can be grasped visually and this was precisely the expectation, formulated through $\mathrm{H} 2$. 
To summarize the findings of the first two hypotheses, higher levels of state intervention in the MMEs in the period 1980s/1990s (H1) clearly emerge from the cross-variety comparison. Consistent with the expectations made in $\mathrm{H} 2$, the same state intervention decreases in the post-Maastricht phase.

\section{MMEs and State Intervention in Wage Bargaining}

The two hypotheses tackled in the previous section allow for the delineation of a path for the alleged role held by the state in the given sphere. Consistently with the expectations made, the Mixed Economies were more interventionist than the coordinated ones in the pre-Maastricht phase and experienced a remarkable decrease in direct state intervention in the post-Maastricht one. This observation supports the idea of the Maastricht treaty as a crucial cornerstone, signalling a new EU regulatory phase, to which the countries had to adjust. The necessity of matching the parameters to join the common currency led the MME countries to enact a strategy oriented to consolidation and convergence towards the EMU core countries that were largely CMEs [41]. Moreover, in accordance with the new EU regulatory phase stressing the relevance of the supply-side reforms, from this moment onwards, the direct role of the state in this process was reduced. Hence, in this context, what does the gatekeeper role of the state look like? Or, in different terms, what are the modifications introduced in the state-mediated coordination channel in this new scenario? The core issue embedded in the next two hypotheses is, therefore, the reconfiguration of the gatekeeper role in the post-Maastricht phase.

The reconfiguration of the state's role in this second phase is made concrete by looking at the evolution of social pacts. Following the definition given by Avdagic et al. [42] those pacts are "publicly announced formal policy contracts between the government and social partners over income, labour market or welfare policies that identify explicitly policy issues and targets, means to achieve them, and tasks and responsibilities of the signatories". This is the rationale on which all the variables concerning social pacts embedded in the ICTWSS database are built upon and enabling one to circumscribe the array of pacts by excluding tacit understandings, symbolic declaration and bilateral agreements, occurring without active involvement of the government as a negotiating party. Also, a bulk of literature has shown that, due to the criteria set by the Maastricht Treaty, the MMEs needed to resort to social pacts between employers' organizations and trade unions $[43,44,45]$. This mediating function carried on by the state constitutes exactly the reconfiguration of the gatekeeper role that the subsequent hypotheses aim to ground.

Focusing on the MMEs, $\mathrm{H} 3$ expects to see an increased relevance of social pacts involving governments, unions and employers in the post-Maastricht phase. Eventually, $\mathrm{H} 4$ completes this account by targeting the relaxation of this configuration, once the external constraints are undermined. In other words, coordinating activity through social pacts is expected to decrease, once the incentives for governments to pursue this activity decline. This is an interesting point given some accounts of the Euro-crisis [46], individuated in the relaxation of the SGP rules, the main determinant leading to intra-Eurozone balance of payment disequilibria. These hypotheses can be formally written as follows:

- H3: The amount of Social Pacts negotiated and signed in the MMEs in the post-Maastricht phase is relatively higher than in the previous time period.

- H4: MMEs'state action in labour relations through Social Pacts is higher when the external constraint (EMU accession and fiscal rule implied by the SGP) is also higher.

The MMEs are the main focus of the analysis and the ICTWSS database is the source of these variables too. Then, tackling $\mathrm{H} 3$ and $\mathrm{H} 4$ certainly implies looking at the variables pacts negotiated and pacts signed, meaning the quantification of the social pacts that were negotiated and signed in the given country. In parallel, since the ultimate objective of both the hypotheses is broader than a pure analysis of social pacts and oriented to tackle the reconfiguration of the gatekeeping role, a further variable denominated sponsored agreements is also added. These agreements, whether or not they imply wage settlements, are excluded from social pact counts, given their less formal nature than the one required in Avdagic et al.'s [47] definition. However, the ICTWSS database allows for distinguishing between bipartite autonomous agreements and sponsored ones. Whereas, in the former group, the state plays no role, in the latter one, the agreement is sponsored by the state or enforced via legislation. In other words, although this second group includes agreements missing the formal requirements to define them as social pacts, the mediating role of the state is clearly also present. Yet, as the aim of the next hypotheses is grounding how the state's role has evolved in the given context, i.e. the MMEs, it seems meaningful to include this second type of agreement in the analysis too. Hence, the variable so elaborated displays the amount of state sponsored agreements settled in the given country, whether or not they imply a specific settlement on wages, and ultimately allows for the inclusion of agreements that are less formal than pacts but still very important in refining the state's role.

Table 3 therefore displays all the countries previously considered as MMEs, i.e. France, Greece, Italy, Spain and Portugal, with reference to the aforementioned variables and along three given time frames. The aggregate data for the overall MME variety is also displayed at the end of the table. For any given country, the first row displays pacts/agreements covered in the ICTWSS database 
(meaning from the 1960), the second one quantifies pacts/agreements in the period from 1991 to 2007, and the third one covers the period from 1991 to 2014. In other words, the first entry constitutes the overall sum of pacts and agreements in the entire period of time (1960-2014) and registered in the ICTWSS database. The second and the third entries show the relative pacts/agreements in the post-Maastricht phase. Specifically, the 1991-2007 time frame is selected to portray the relative quantity of pacts/agreements, settled before the eruption of both the financial and the Euro crises, whereas the 1991-2014 time frame covers all the post-Maastricht phase. An additional column showing the percentage of pacts/agreement over the total number is finally displayed.

Before entering the details, it has to be considered that in all the countries, except Portugal where the data begin from mid-1970s, the entry concerning all the database covers a time frame ranging from 1960 to 2014, so that the pre-Maastricht phase is longer than the post-Maastricht one. Despite this caveat, all the considered countries seem to have a higher percentage of both social pacts and state sponsored agreement in this latter phase. Italy, Portugal and Spain all range around $50 \%$ of the pacts negotiated in the period from 1991-2007. This data is further increased if the time frame is extended until 2014. Similar considerations can be made about the state-sponsored agreements. Greece records all its negotiated social pacts, and about a third of the extremely numerous sponsored agreements in this specific phase. France constitutes a partial exception, with only one pact negotiated in the post-Maastricht phase. This data does not come as a surprise given that France was significantly more aligned with the German business cycles before the EMU's launch and, therefore, was not required to sustain a consolidation effort, like the other countries. It is argued that this was only a partial exception because, observing the state-sponsored agreements, even the picture concerning France is much more nuanced, given $50 \%$ ca. of the numerous agreements were signed in this phase. At any rate, the aggregate data grouping all the MMEs confirmed the expected path, meaning an increased salience of both pacts and the state sponsored agreements in the post-Maastricht phase. To summarize the issue, the expectations made through $\mathrm{H} 3$ appear to be matched by the data observable through the selected variables.

Table 3. Amount of social pacts and state sponsored agreements in the MMEs countries - ICTWSS data, own elaboration

\begin{tabular}{|c|c|c|c|c|}
\hline Country/Years & Pacts Negotiated & Pacts Signed & Sponsored Agreements & Percentage/Total \\
\hline Italy all database & 12 & 11 & 5 & - \\
\hline Italy 1991-2007 & 6 & 6 & 2 & $50 \% / 54 \% / 40 \%$ \\
\hline Italy 1991-2014 & 9 & 8 & 4 & $75 \% / 73 \% / 80 \%$ \\
\hline Greece all database & 3 & 1 & 36 & - \\
\hline Greece 1991-2007 & 3 & 1 & 11 & $100 \% / 100 \% / 31 \%$ \\
\hline Greece 1991-2014 & 3 & 1 & 13 & $100 \% / 100 \% / 36 \%$ \\
\hline Spain all database & 13 & 8 & 6 & - \\
\hline Spain 1991-2007 & 6 & 2 & 5 & $46 \%$ / $25 \% / 83 \%$ \\
\hline Spain 1991-2014 & 7 & 3 & 5 & $54 \% / 37 \% / 83 \%$ \\
\hline Portugal all database & 15 & 13 & 3 & - \\
\hline Portugal 1991-2007 & 9 & 8 & 3 & $56 \% / 61 \% / 100 \%$ \\
\hline Portugal 1991-2014 & 13 & 11 & 3 & $81 \% / 85 \% / 100 \%$ \\
\hline France all database & 2 & 1 & 21 & - \\
\hline France 1991-2007 & 1 & 0 & 9 & $50 \% /-/ 43 \%$ \\
\hline France 1991-2014 & 1 & 0 & 12 & $50 \% /-/ 52 \%$ \\
\hline MMEs all database & 46 & 34 & 69 & - \\
\hline MMEs 1991-2007 & 25 & 17 & 30 & $54 \% / 50 \% / 43 \%$ \\
\hline MMEs 1991-2014 & 33 & 23 & 37 & $72 \% / 68 \% / 54 \%$ \\
\hline
\end{tabular}


Once observed, the increased relevance of social pacts and state sponsored agreements in the post-Maastricht phase, one's attention can be turned to the last hypothesis. Consistent with the expectations stemming from the peculiar gatekeeper role of the state in the Mixed countries and the literature on the external constraint $[48,49], \mathrm{H} 4$ envisions a reduced number of pacts/agreements, once the external constraint is weakened. In other words, the coordinating activity through social pacts is expected to decrease once the incentives decline. Also, the moment where these incentives clearly decline can be individuated in 2003, when both France and Germany violated the clauses of the Stability and Growth Pact (SGP), without being sanctioned by the Commission. This choice is justified by the fact that once the EMU accession was secured, the only constraint remained to enact a strong coordination in wage bargaining was the fiscal discipline imposed by the SGP. So, obviously, once the substance of the SGP is modified, this constraint is significantly weakened. To sum up, $\mathrm{H} 4$ expects to see a higher number of pacts/agreements in the initial phase, ranging from 1992 to 2003, compared to the second one, when the external constraint is weakened and ranging from 2004 to 2013. In 2013, indeed, the Treaty on Stability, Coordination and Governance in the EMU (TSGC) entered in force completing the so-called Sixpack/Twopack regulations, to constitute the new fiscal rule within the Eurozone.

Table 4. Amount of social pacts and state sponsored agreements in the given time period - ICTWSS data, own calculation

\begin{tabular}{|c|c|c|c|}
\hline Country/Years & $\begin{array}{c}\text { Pacts } \\
\text { Negotiated }\end{array}$ & $\begin{array}{c}\text { Pacts } \\
\text { Signed }\end{array}$ & $\begin{array}{c}\text { Sponsored } \\
\text { Agreements }\end{array}$ \\
\hline Italy 1992-2003 & 5 & 5 & 2 \\
\hline Italy 2004-2013 & 4 & 3 & 2 \\
\hline $\begin{array}{c}\text { Greece } \\
\text { 1992-2003 }\end{array}$ & 3 & 1 & 8 \\
\hline $\begin{array}{c}\text { Greece } \\
\text { 2004-2013 }\end{array}$ & 0 & 0 & 4 \\
\hline Spain 1992-2003 & 4 & 1 & 5 \\
\hline Spain 2004-2013 & 2 & 2 & 0 \\
\hline $\begin{array}{c}\text { Portugal } \\
1992-2003\end{array}$ & 6 & 4 & 0 \\
\hline $\begin{array}{c}\text { Portugal } 2004-2013 \\
\text { France } \\
1992-2003\end{array}$ & 1 & 7 & 2 \\
\hline $\begin{array}{c}\text { France } \\
2004-2013\end{array}$ & 0 & 0 & 4 \\
\hline $\begin{array}{c}\text { MMEs } \\
1992-2003\end{array}$ & 19 & 11 & 23 \\
\hline $\begin{array}{c}\text { MMEs } \\
2004-2013\end{array}$ & 13 & 10 & 12 \\
\hline
\end{tabular}

Subsequently table 4 therefore allows for the observation that, in all the MME countries, except for Portugal, a decrease of pacts/agreements occurred in the second phase highlighted here. Moreover, looking at the aggregate data, a reduction of negotiated pacts (from 19 to 13) and a substantial halving of state sponsored agreements (from 23 to 12) can be observed. Also, the data concerning negotiated pacts, in the second phase, is significantly driven by Portugal, that account for around half of the registered pacts.

Eventually, Figure 4, by displaying the three years' moving average of the considered variables, gives further information about the trend, with regard to the aggregated MMEs' data. More in detail, it is particularly interesting to note that the lower peaks of both negotiated and signed pact variables coincide with 1999 and 2004; that is to say, the year where the EMU was set and the one immediately after the aforementioned Franco-German violation of the fiscal rule. This fact strengthens the idea of the effect of external constraints over state willingness to resort to pacts. In other words, pacts emerged in countries where corporatist institutions were traditionally absent, like the MMEs, are extremely sensitive to external constraints. This finding seems consistent with the accounts individuating in the absence of wage bargaining coordination in MMEs - especially after the EMU creation - the roots of the balance of payment disequilibria that ultimately led to the Euro-crisis $[50,51,52]$

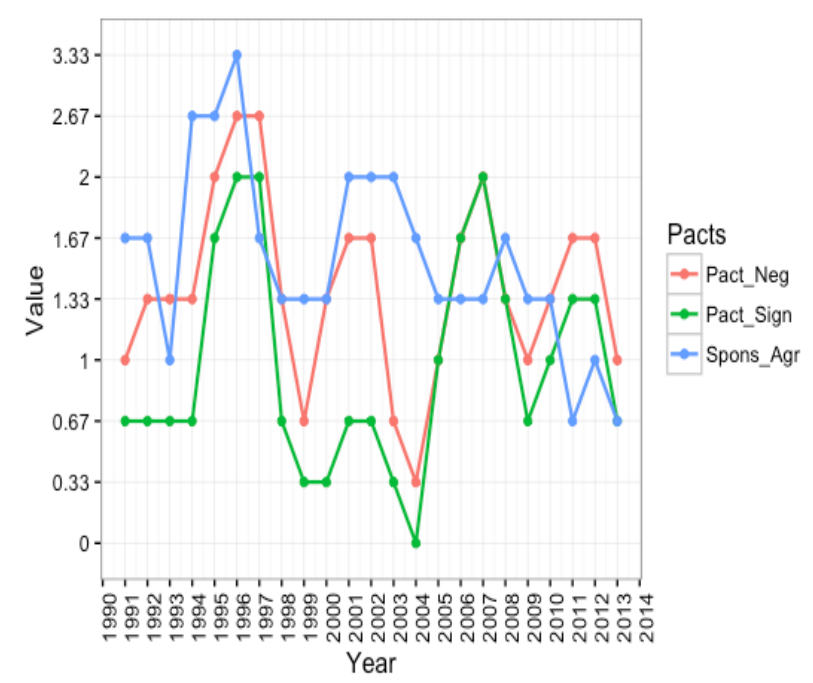

Figure 4. Rolling average of social pacts and state sponsored agreements in the MMEs (1991-2013) - ICTWSS data, own elaboration

To summarize the findings of $\mathrm{H} 3$ and $\mathrm{H} 4$, two considerations are required. Firstly, and consistently with the hypotheses that were made, a reconfiguration of the gatekeeper role of the state in the post-Maastricht phase assumed the semblance of increased intervention via social pacts or via state sponsored agreements. Secondly, external constraint seems to play a crucial role in the effectiveness of these channels. In other terms, in the post-Maastricht phase, an attempt to improve coordination in wage bargaining via social pacts and state sponsored agreements - i.e. a partial convergence toward the CMEs side occurred, through a reconfiguration of the gatekeeping role of the state. However, this process of convergence revealed all its intrinsic fragilities, once the constraint is weakened and possibly led to the process of divergence that CMEs 
and MMEs have experienced at the eve of the Euro-crisis.

\section{Conclusions}

A close inspection of labour relations allows for the making of a few conclusive statements about the gatekeeper role of the state as the main feature in the MMEs' channel of coordination. Although section 2 showed that institutional complementarities exist in the MMEs, these contexts are recognized as having the weakest linkages amongst the sub-systems that allegedly make them more sensitive to the external pressures. Due to this feature and the peculiar mediating nature that the state pursues, there are no reasons to assume the gatekeeper role has a static nature. The first observation that can be drawn from this paper is, indeed, that the gatekeeper role of the state is not a fixed concept but its intrinsic configuration varies according to the European regulatory scenario. The strong interrelation between the phases of the Europeanization process and the configuration of the gatekeeper role is probably the most interesting aspect emerging from the research. For instance, the findings confirm the idea that the Maastricht Treaty and the path toward a common currency, i.e. a remarkable change for the domestic political economies, engendered modification in the gatekeeper role too. Higher levels of direct state intervention in wage bargaining was observable in the 1980s and 1990s, but a completely different picture can be drawn, once attention is turned to the post-Maastricht phase, when the same direct intervention falls steeply. The second observation concerns the findings stemming from the third and the fourth hypotheses, where the focus switched from a cross-variety comparison to an in-depth analysis of the MMEs in the post-Maastricht phase. The reconfiguration of the gatekeeper role occurred via significant increases in both social pact and state sponsored agreements and was revealed to be extremely sensitive to the presence of an external constraint. However, the reconfiguration, rather than the demise of the gatekeeper role, also implies that this feature remained the most important one in the MMEs' coordination channel.

To sum up, the findings displayed in this article have a twofold relevance. On the one hand, the underlying rationale for the gatekeeper role held by the state was displayed during various decades in a crucial political economy dimension, like labour relations. Following this investigation, the relevance of this peculiar feature in the coordination channel of the MMEs is also strengthened. On the other hand, the changes observed in the gatekeeper configuration, and resulting from substantive innovation at the European level, constitute a fundamental step in the direction to target interrelations and problematic interdependencies between the EMU's institutional framework and the national varieties of capitalism. The necessity to closely investigate those linkages and the related consequences is the main issue stemming from the VoC-based analyses in the aftermath of the Euro-crisis, indeed.

\section{REFERENCES}

[1] Nölke, A. (2016). 'Economic causes of the Eurozone crisis: The analytical contribution of comparative capitalism'. Socio-Economic Review, 14(1): 141-161.

[2] Hall, P.A. (2012). 'The Economics and Politics of the Euro Crisis'. German Politics, 21(4): 355-371.

[3] Hancké, B. (2013). Unions, central banks and EMU: labour market institutions and monetary integration in Europe, Oxford: Oxford University Press.

[4] Hassel, A. (2014). 'Adjustments in the Eurozone: Varieties of Capitalism and the Crisis in Southern Europe'. LSE "Europe in Question” Discussion Paper Series, 76(14).

[5] Höpner, M. and Lutter, M. (2014). 'One Currency and Many Modes of Wage Formation Why the Eurozone Is Too Heterogeneous for the Euro'. MPIfG discussion paper, 14(14).

[6] Johnston, A., Hancké, B. and Pant, S. (2014). 'Comparative Institutional Advantage in the European Sovereign Debt Crisis'. Comparative Political Studies, 47(13): 1771-1800.

[7] Johnston, A. and Regan, A. (2016). 'European Monetary Integration and the Incompatibility of National Varieties of Capitalism'. Journal of Common Market Studies, 54(2): 328-336.

[8] Rhodes, M. and Molina, O. (2007). 'The Political Economy of Adjustment in Mixed Market Economies: A Study of Spain and Italy'. In B. Hancké, M. Rhodes, and M. Thatcher (eds.) Beyond Varieties of Capitalism. Oxford: Oxford University Press, 223-252

[9] Boltho, A. and Carlin, W. (2013). 'EMU's Problems: Asymmetric Shocks or Asymmetric Behavior?' Comparative Economic Studies, 55: 387-403.

[10] Walter, S. (2016). 'Crisis Politics in Europe: Why Austerity Is Easier to Implement in Some Countries Than in Others'. Comparative Political Studies, 49(7): 841-873.

[11] Visser, J. (2015). 'ICTWSS Data base - version 5.0'. Amsterdam: Amsterdam Institute for Advanced labour Studies (AIAS).

[12] Cerny, P.G. (1997). 'Paradoxes of the Competition State: The Dynamics of Political Globalization'. Government and Opposition, 32(2): 251-274.

[13] Cerny, P.G. (1999). 'Globalization and the erosion of democracy'. European Journal of Political Research, 36(1): $1-26$.

[14] Rajan, R.G. and Zingales, L. (2003). 'The great reversals: The politics of financial development in the twentieth century'. Journal of Financial Economics, 69(1): 5-50.

[15] Hall, P.A. and Soskice, D. (2001). Varieties of Capitalism: 
The Institutional Foundations of Comparative Advantage, Oxford: Oxford University Press.

[16] Hancké, B., Rhodes, M. and Thatcher, M. (2007). Beyond Varieties of Capitalism, Oxford: Oxford University Press.

[17] Hall, P.A. and Gingerich, D.W. (2004). 'Varieties of Capitalism and Institutional Complementarities in the Macroeconomy an Empirical Analysis'. MPIfG Discussion Paper, 04/5.

[18] Della Sala, V. (2004). 'The Italian model of capitalism: on the road between globalization and Europeanization?' Journal of European Public Policy, 11(6):1041-1057.

[19] Simoni, (2012). 'Institutional Roots of Economic Decline Lessons from Italy?, European Institute. London School of Economics and Political Science.

[20] Rhodes, M. and Molina, O. (2007). 'The Political Economy of Adjustment in Mixed Market Economies: A Study of Spain and Italy'. In B. Hancké, M. Rhodes, and M. Thatcher (eds.) Beyond Varieties of Capitalism. Oxford: Oxford University Press, 223-252.

[21] Hancké, B. (2011). 'Varieties of European Capitalism and their Transformation'. In P. Heywood, E. Jones, M. Rhodes and U. Sedelmeier (eds.) Developments in European Politics - 2nd Edition. New York: Palgrave Macmillan, 155-172.

[22] Hall, P.A. (2012). 'The Economics and Politics of the Euro Crisis'. German Politics, 21(4): 355-371.

[23] Regan, A. (2015). 'The imbalance of capitalisms in the Eurozone: Can the north and south of Europe converge?', Comparative European Politics, 2: 1-22.

[24] Gambarotto, F. and Solari, S. (2015). 'The peripheralization of Southern European capitalism within the EMU'. Review of International Political Economy, 22(4): 788-812.

[25] Herrmann, A. (2008). 'Contrasting the resource-based view and competitiveness theories: how pharmaceutical firms choose to compete in Germany, Italy and the UK'. Strategic Organization, 6(4): 343-374.

[26] De Ville, F. and Vermeiren, M. (2016). 'The Eurozone crisis and the rise of China in the global monetary and trading system: The political economy of an asymmetric shock'. Comparative European Politics. 14(4): 572-603.

[27] Lane, C. and Wood, G. (2009). Capitalist diversity and diversity within capitalism. Economy and Society, 38(4): 531-551.

[28] Wood, G., Deeg, R. and Wilkinson, A. (2014). 'The Rise and Fall of Complementarity and National Institutional Orders'. The Journal of Comparative Economic Studies, 9: 29-46.

[29] Ferrera, M. (1996). 'The "Southern Model" of Welfare in Social Europe'. Journal of European Social Policy, 6(1): $17: 37$.

[30] Ferrera, M. and Gualmini, E. (2004). Rescued by Europe? Social and Labour Market Reforms in Italy from Maastricht to Berlusconi, Amsterdam: Amsterdam University Press.

[31] Beramendi, P., Häusermann, S. and Kitschelt, H. (2015). The Politics of Advanced Capitalism, Cambridge: Cambridge University Press.
[32] Hassel, A. (2014). 'Adjustments in the Eurozone: Varieties of Capitalism and the Crisis in Southern Europe'. LSE "Europe in Question" Discussion Paper Series, 76(14).

[33] Hancké, B. (2013). Unions, central banks and EMU: labour market institutions and monetary integration in Europe, Oxford: Oxford University Press.

[34] Armingeon, K. and Baccaro, L. (2012). 'Political economy of the sovereign debt crisis: The limits of internal devaluation'. Industrial Law Journal, 41(3): 254-275.

[35] Matthijs, M. (2014). 'Mediterranean Blues: the Crisis in Southern Europe'. Journal of Democracy, 25(1): 101-115.

[36] Tabellini, G. (2015). 'The main lessons to be drawn from the European financial crisis'. In R. Baldwin and F. Giavazzi (eds.) The Eurozone Crisis A Consensus View of the Causes and a Few Possible Remedies. London: CEPR Press, 170 175

[37] Hassel, A. (2006). Wage Setting, Social Pacts and the Euro A New Role for the State, Amsterdam: Amsterdam University Press.

[38] Kenworthy, L. (2001). 'Wage-Setting Institutions: A survey and assessment'. World Politics, 54: 35.

[39] Hassel, A. (2006) Wage Setting, Social Pacts and the Euro A New Role for the State, Amsterdam: Amsterdam University Press.

[40] Visser, J. (2015). 'ICTWSS Data base - version 5.0'. Amsterdam: Amsterdam Institute for Advanced labour Studies (AIAS)

[41] Hancké, B. (2013). Unions, central banks and EMU: labour market institutions and monetary integration in Europe, Oxford: Oxford University Press

[42] Avdagic, S., Rhodes, M. and Visser, J. (2011). Social Pacts in Europe, Oxford: Oxford University Press, p.10.

[43] Hassel, A. (2003). 'The Politics of Social Pacts'. British Journal of Industrial relations, 41(4): 707-726.

[44] Pochet, P., Keune, M. and Natali, D. (2010). After the euro and enlargement: social pacts in the EU, Brussels, Brussels: ETUI Publications.

[45] Hancké, B. and Rhodes, M. (2005). 'EMU and Labor Market Institutions in Europe The Rise and Fall of National Social Pacts'. Work and Occupations, 20(10): 1-33.

[46] Baskaran, T. and Hessami, Z. (2013). 'Monetary Integration, Soft Budget Constraints, and the EMU Sovereign Debt Crises'. Working Paper Series of the Department of Economics - University of Konstanz, 3. Available at:http://www.uni-konstanz.de/FuF/wiwi/workingpaperseri es/WP 03-Baskaran_Hessami_2013.pdf.

[47] Avdagic, S., Rhodes, M. and Visser, J. (2011). Social Pacts in Europe, Oxford: Oxford University Press.

[48] Featherstone, K. (2001). 'The Political Dynamics of the Vincolo Esterno: The Emergence of EMU and the Challenge to the European Social Model'. Queen's Papers on Europeanization, (6).

[49] Featherstone, K. and Radaelli, C.M. (2003). The Politics of Europeanization, Oxford: Oxford University Press. 
[50] Regan, A. (2013). 'Political Tensions in Euro-Varieties of Capitalism: the Crisis of the Democratic State in Europe'. EUI Working Papers. Available at: http://cadmus.eui.eu/bitstream/handle/1814/28177/MWP_2 013_24.pdf? sequence=1\&isAllowed $=y$.

[51] Johnston, A. and Regan, A. (2016). 'European Monetary
Integration and the Incompatibility of National Varieties of Capitalism'. Journal of Common Market Studies, 54(2): 328-336.

[52] Hancké, B. (2013). Unions, central banks and EMU: labour market institutions and monetary integration in Europe, Oxford: Oxford University Press. 